UDC 632:95.024:[616.15+577.161]

\title{
BIOCHEMICAL AND HAEMATOLOGICAL CHANGES IN PERIPHERAL BLOOD OF RATS EXPOSED TO CHLORPYRIFOS: PROTECTIVE EFFECT OF VITAMINS A AND E COMBINATION
}

\author{
V. P. Rosalovsky, S. V. Grabovska, Yu. T. Salyha \\ Institute of Animal Biology, NAAS of Ukraine, 38, V. Stus St., Lviv 79034, Ukraine \\ e-mail:ros.volodymyr@gmail.com
}

Chlorpyrifos is a highly toxic organophosphate compound. It is still among the most widely used insecticide, and the main mechanism of its toxicity is associated with inhibition of cholinesterases. A long with the anticholinesterase action, CPF may affect other biochemical mechanisms, particularly through disrupting pro- and antioxidant balance and inducing free-radical oxidative stress.

We studied the action of $A$ and $E$ vitamins on the basic haematological and biochemical parameters of rat peripheral blood after 12 hours of a single chlorpyrifos intoxication. Exposure to $70 \mathrm{mg} / \mathrm{kg}$ chlorpyrifos caused a decrease in the total number of red blood cells (RBCs), platelets, and total haemoglobin content. We also observed a decrease in the acid haemolysis resistance of RBCs in peripheral blood of CPF-poisoned rats. Combined exposure to chlorpyrifos and vitamins $A$ and $E$ caused changes in haemolysis resistance of RBCs, approaching the control values. In addition, it was found that chlorpyrifos intoxication disrupt prooxidant-antioxidant balance as evidenced by the increase of lipid peroxidation products: lipid hydroperoxides and thiobarbituric acid reactive substances. However, administration of vitamins $A$ and $E$ during intoxication provided levelling effect on the formation of lipid peroxidation products. CPF intoxication caused an increase of the catalase activity, while superoxide dismutase, glutathione peroxidase and glutathione reductase activities and the content of reduced glutathione decreased. It was revealed that combination of vitamins $A$ and $E$ cause corrective effect at the platelets quantity, and lipid hydroperoxides thiobarbituric acid reactive substances amount of rat peripheral blood.

Keywords: chlorpyrifos, vitamin E, vitamin A, intoxication, rats.

\section{INTRODUCTION}

Organophosphorous compounds (OPs) belong to a group of phosphonic or phosphoric acid derivatives, widely used in agriculture, primarily as components of insecticides, defoliants and means against animal ectoparasites. The most frequent causes of acute OP poisonings are violation of personnel safety regulations, accidental intake, and suicidal attempts [13].

ISSN 1996-4536 (print) • ISSN 2311-0783 (on-line) • Біологічні Студії / Studia Biologica • 2015 • Том 9/№3-4 • С. 57-68 
The main mechanism of OP toxicity is cholinesterase (ChE) inhibition in plasma and erythrocytes, caused by phosphorylation of serine hydroxyl residue in the enzyme molecule. Resulting accumulation of non-hydrolyzed acetylcholine leads to violations in neuromuscular synaptic transfer and respiratory depression $[2,22]$.

A typical representative of OPs is Chlorpyrifos (CPF) $\left(\mathrm{C}_{9} \mathrm{H}_{11} \mathrm{Cl}_{3} \mathrm{NO}_{3} \mathrm{PS}\right)$, both in pure form and in combinations with other substances, is widely used in agriculture, industrial and home disinfection, to control harmful and synanthropic insects [9, 24, 28].

Numerous studies indicate neuro-, hepato- and cytotoxic effects of CPF $[2,8,20-$ $21,23]$. There is evidence that CPF intoxication leads to disruption of pro- and antioxidant balance and causes formation of reactive oxygen species (ROS). The latter have high reactivity and can modify the biological structure of blood cells, including erythrocytes, impairing their resistance to damage and membrane integrity [6, 22].

Red blood cells transport oxygen and carbon dioxide between lungs and tissues. They can be subjected to oxidative damage due to the high oxygen tension, high content of polyunsaturated fatty acids (PUFAs) in plasma membranes. Moreover, due to haemoglobin oxidation, ferrum valence changes, and the emitted electron can modify the oxygen molecule $\left(\mathrm{Fe}^{2+} \rightarrow \mathrm{Fe}^{3+}+\mathrm{e}^{-}\right)$. However, RBCs have an antioxidant defence system, which includes enzymatic components superoxide dismutase (SOD), catalase (CAT), glutathione peroxidase (GPO), glutathione reductase (GR) and non-enzymatic ROS-scavengers: reduced glutathione (GSH) and vitamins $A$ and $E$ [2].

Due to the double bonds, vitamin $A$ is involved in the regulation of redox reactions.

Another fat-soluble antioxidant is vitamin E. Its action is aimed to activate tissue respiration and keep the steady level of free radical peroxidation. Tocopherol reacts with ROS, producing inactive compounds and disrupting the ROS formation chain; it protects PUFAs of the cell membrane. It is known that vitamin E increases the biological activity of vitamin A, preventing oxidation of its unsaturated side chain [1,2].

According to existing data, the consequences of OP intoxication include changes in the activity of antioxidant system enzymes and initiation of lipid peroxidation (LPO) [22].

There are data on the use of vitamins C, E, A in the OP intoxications treatment $[10,24]$. However, these works relate to antioxidant defence system, while the physiological parameters of blood components are studied rather poorly [2].

The aim of this work was to study the main haematological and biochemical parameters of rat peripheral blood after 12 hours of a single CPF exposure and in combination with vitamins $A$ and $E$.

\section{MATERIALS AND METHODS}

The study was conducted on 20 adult male Wistar rats of $180-220 \mathrm{~g}$ body weight. The animals were kept in standard vivarium conditions, with 12-hour dark/light mode and unlimited access to water and lab food. All manipulations with animals were carried out according to the European Convention "On protection of vertebrate animals used for experimental and scientific purposes" (Strasbourg, 1986) and "General ethical principles of experiments on animals" (First National Congress on Bioethics, Kyiv, 2001).

Animals were divided into four groups: 1 control $(C)$ and 3 experimental (E1, E2, E3) groups of 5 rats each. Animals in group E1 were exposed to $70 \mathrm{mg} / \mathrm{kg}$ chlorpyrifos in oil solution; E2 group animals received $0,055 \mathrm{~g}$ vitamin $\mathrm{A}$ (in the retinol palmitate form) and $0.1 \mathrm{~g}$ vitamin $\mathrm{E}$ (alpha tocopherol in the acetate form); animals from E3 group were exposed to both CPF solution $(70 \mathrm{mg} / \mathrm{kg})$ and vitamins $A(0.055 \mathrm{~g})$ and $E(0.1 \mathrm{~g})$. The

ISSN 1996-4536 (print) • ISSN 2311-0783 (on-line) • Біологічні Студії / Studia Biologica • 2015 • Том 9/№3-4 • С. 57-68 
animals of groups E2 and E4 were administered of vit. A and E solution 5 minutes later after CPF exposure. All exposures were conducted intragastrically via oral gavage. The control group received a corresponding amount of pure oil. After 12 hours of CPF, animals were euthanized with ether anaesthesia and decapitated and peripheral blood was collected.

For study of haematological parameters, blood samples were put in test tubes

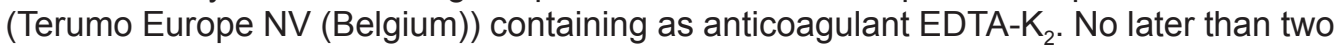
hours after sampling, blood was studied in automatic haematological analyzer (Orphee Mythic 18, Switzerland). The following parameters were studied: the number of RBCs, white blood cells, lymphocytes, monocytes, granulocytes, platelets, haemoglobin concentration, haematocrit, and mean platelet volume and platelet volume heterogeneity index. RBC resistance to acid haemolysis was determined by Terskov and Gitel'zon [7].

For biochemical studies, heparinized blood samples were centrifuged for 15 minutes at $1,500 \mathrm{~g}$. After plasma separation, erythrocytes were washed three times with $0.15 \mathrm{M}$ $\mathrm{NaCl}$ solution. Haemolysates were obtained by three times freezing-thawing of aqueous suspensions of RBCs and their subsequent centrifugation at 10,700 $\mathrm{g}$ for $15 \mathrm{~min}$.

Cholinesterase (ChE) (EC 3.1.1.8) activity in plasma was determined by Karpyshtshenko [12], using the commercial kit by "Filisit-Diagnostics" (Ukraine). Optical absorbance was measured spectrophotometrically at $540 \mathrm{~nm}$ against distilled water.

Superoxide dismutase (SOD) (EC 1.1.15.1.) activity was determined by Dubinina et al. [5], based on the reduction of nitroblue tetrazolium to nitroformazan by superoxide anion, that are formed in the reaction between phenazine methosulphate and NADPH. SOD activity was expressed in arbitrary units per $1 \mathrm{mg}$ protein.

Catalase (CAT) (EC 1.11.1.6) activity in the haemolysates was determined by Koroliuk [15] with modifications. The method is based on the ability of hydrogen peroxide to form a stable colored complex with molybden salts. Enzyme activity was expressed in mmol $\mathrm{H}_{2} \mathrm{O}_{2} /$ min per $1 \mathrm{mg}$ protein using a molar absorption coefficient $22200 \mathrm{M}^{-1} \mathrm{~cm}^{-1}$.

Glutathione peroxidase (GPO) (EC 1.11.1.9) activity was determined by the rate of GSH oxidation before and after incubation with tertiary butyl hydroperoxide. This colour reaction is based on the interaction between $\mathrm{SH}$-groups with the 5,5'-dithiobis(2-nitrobenzoic acid) (DTNBA), resulting in a colored product, thionitrophenyl anion [18]. Quantity of the thionitrophenyl anion is directly proportional to the number of SH-groups reacted with DTNBA. Enzyme activity was expressed in $\mu \mathrm{mol} \mathrm{GSH} / \mathrm{min}$ per $1 \mathrm{mg}$ protein.

Glutathione reductase (GR) (EC 1.6.4.2) activity was determined by Carlberg [3]. This method is based on the catalytic NADPH-dependent reduction of oxidized glutathione form, the intensity of which can be measured by the rate of extinction decline on the wavelength of NADPH maximum absorption $340 \mathrm{~nm}$. Calculation of GR activity was carried out using molar absorption coefficient for NADPH $6200 \mathrm{M}^{-1} \mathrm{~cm}^{-1}$. The activity of the enzyme was expressed in $\mu \mathrm{mol} \mathrm{NADPH} / \mathrm{min}$ per $1 \mathrm{mg}$ of protein.

The concentration of reduced glutathione (GSH) was measured spectrophotometrically before and after the reaction, by Hissin [11]. The colour reaction is based on the interaction between SH-groups of GSH and DTNBA. The GSH content was calculated with the calibration curve.

The content of lipid hydroperoxides (LP) in erythrocyte mass was determined by [27], based on spectrophotometric measurement of optical density of products formed in the reaction between ammonium thiocyanate, Mohr's salt and hydrochloric acid.

ISSN 1996-4536 (print) • ISSN 2311-0783 (on-line) • Біологічні Студії / Studia Biologica • 2015 • Том 9/№3-4 • С. 57-68 
The concentration of thiobarbituric acid reactive substances (TBARS), characterizing the LPO rate, was determined by Korobeinikova, based on the reaction between malondialdehyde (MDA) and thiobarbituric acid (TBA), in conditions of high temperature and acidic environment, with formation of a colored trimethyl complex consisting of one MDA and two TBA molecules [14].

Protein concentration was determined by Lowry method [16].

All reagents used were obtained from Sigma-Aldrich and Fluka (USA).

Obtained data were analyzed statistically with Student's t-test, using the program OriginPro 8. Data considered statistically significant at $p<0.05$.

\section{RESULTS AND DISCUSSION}

The basic integral marker of OP intoxication is a decrease in cholinesterase activity. The phosphorylation of cholinesterase leads to loss of its ability to hydrolyze acetylcholine. Because of this, we studied cholinesterase activity in blood plasma of all groups of animals (Fig. 1).

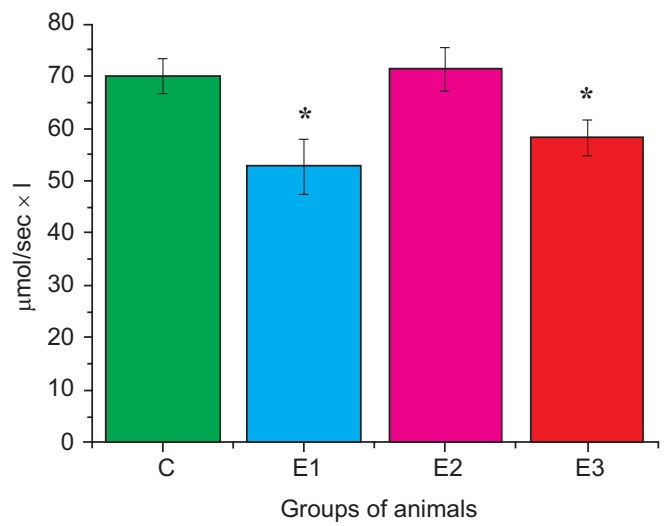

Fig. 1. A blood plasma ChE activity of rats groups C, E1, E2, E3

Here and later: * $-p<0.05$ significant difference compared to control group; $\#-p<0.05$ significant difference compared to $\mathrm{E} 1$ group

Рис. 1. Активність холінестерази у плазмі крові щурів груп C, E1, E2, E3

Тут і далі: * - p<0,05 різниця достовірна порівняно із контрольною групою; \# $\mathrm{p}<0,05$ різниця достовірна порівняно із групою $\mathrm{E} 1$

The results indicate that CPF intoxication caused a decrease of ChE activity by $24.5 \%$ in the blood of group E1. Changes in the ChE activity are the primary characteristics of OP intoxication, as confirmed by the literature [17].

Notably, in the blood plasma of E3 animals, ChE activity decreased only by $14 \%$, comparing with the intact animals. No significant differences in ChE activity were found between E1 and E3 groups.

On the next research stage, we studied the haematological parameters of peripheral blood. The results are presented in Table 1.

At $12^{\text {th }}$ hour after CPF exposure, a significant decrease in platelet count was observed in the peripheral blood of E1 group rats, which are consistent with results of our previous studies [19]. In addition, in this group was found a significant decrease in the number of RBCs (by $14 \%$ ) and haemoglobin content (by $8 \%$ ), compared with control values. According to S. F. Ambali, this decrease may be caused by the formation of cross-links between proteins and lipids of the cell membrane and inactivation of enzymes located in the cell. By-products of LPO can cause violations in composition and structure of membranes, extrude essential fatty acids, and inactivate membrane-bound enzymes. [2].

ISSN 1996-4536 (print) • ISSN 2311-0783 (on-line) • Біологічні Студії / Studia Biologica • 2015 • Том 9/№3-4 • С. 57-68 
Table 1. Peripheral blood parameters in C, E1, E2, E3 groups of rats

Таблиця 1. Параметри периферичної крові у групах щурів C, E1, E2, E3

\begin{tabular}{|c|c|c|c|c|}
\hline Parameters & C & E1 & E2 & E3 \\
\hline Red blood cells, $10^{12} / \mathrm{l}$ & $8.18 \pm 0.27$ & $7.08 \pm 0.32^{*}$ & $7.58 \pm 0.25$ & $7.25 \pm 0.31$ \\
\hline Total haemoglobin, g/l & $153.8 \pm 3.37$ & $141.5 \pm 4.05^{*}$ & $149.3 \pm 5.32$ & $142.8 \pm 5.8$ \\
\hline Haematocrit, (HCT) I/I & $0.44 \pm 0.03$ & $0.39 \pm 0.04$ & $0.4 \pm 0.03$ & $0.39 \pm 0.13$ \\
\hline Mean cell volume, $(\mathrm{MCV}) \mathrm{fl}$ & $54.54 \pm 1.66$ & $55.07 \pm 2.65$ & $53.36 \pm 2.18$ & $56.08 \pm 2.48$ \\
\hline Leukocytes, $10^{9} / 1$ & $11.06 \pm 2.2$ & $7.7 \pm 1.16$ & $5.42 \pm 2.02$ & $5.56 \pm 1.01$ \\
\hline Lymphocytes, $10^{9} / 1$ & $8.06 \pm 1.41$ & $5.92 \pm 2.43$ & $5.38 \pm 2.53$ & $8.48 \pm 2.08$ \\
\hline Granulocytes, $10^{9} / 1$ & $1.12 \pm 0.7$ & $0.62 \pm 0.29$ & $0.2 \pm 0.07$ & $0.44 \pm 0.21$ \\
\hline Monocytes, $10^{9} / \mathrm{I}$ & $1.9 \pm 0.25$ & $1.15 \pm 0.56$ & $0.92 \pm 0.44$ & $1.44 \pm 0.32$ \\
\hline Platelets, $10^{9} / 1$ & $425.8 \pm 23.7$ & $314.2 \pm 37.6^{*}$ & $307.8 \pm 45.5$ & $468.8 \pm 29.5^{\#}$ \\
\hline Mean platelet volume, (MPV) fl & $6.6 \pm 0.33$ & $7.5 \pm 0.85$ & $7.4 \pm 1,02$ & $7.3 \pm 0.99$ \\
\hline Platelet distribution width, (PDW) \% & $20.02 \pm 3.47$ & $17.72 \pm 4.4$ & $22.98 \pm 8.27$ & $16.22 \pm 3.36$ \\
\hline
\end{tabular}

Comments: Here and later: * $-p<0.05$ significant difference compared to control group; $\#-p<0.05$ significant difference compared to $\mathrm{E} 1$ group

Примітки: Тут і далі: * - p<0,05 різниця достовірна порівняно з контрольною групою; \# - p<0,05 різниця достовірна порівняно з групою Е1

We did not found any significant changes in the total amount of leukocytes, lymphocytes, granulocytes, monocytes in E1, E2, E3 groups, compared to control. In the E2 group, the platelet number slightly decreased, but this decrease was not statistically significant. In the E3 group was observed a significant increase in the total platelet number, compared to $\mathrm{E} 1$ group. It is possible, that increase total quantity of platelets may be associated with antioxidant properties of both vitamins. Being well known antioxidants, vitamin $E$ and A prevent the free-radical mediated damage of the platelets [1, 2].

We have not detected significant intergroup differences between E1 and E3 groups. Minor changes in the number of RBCs in peripheral blood may be associated with changes in physical and chemical properties of erythrocyte membranes and duration of their life under CPF intoxication.

Moreover, vitamin $\mathrm{E}$ influences the cellular response to oxidative stress through modulation of signal-transduction pathways. According to S. F. Ambali [2], these pathways may provide the cellular regulation level. Lipid peroxidation can cause changes in rheological properties of erythrocyte membranes and membrane potential, increase their permeability for different ions that can initiate the process of haemolysis, and thus reduce the lifespan of erythrocytes [1].

To assess the stability of erythrocyte membranes, we studied their resistance to acid haemolysis (Fig. 2). The results are presented in Tab. 2.

Studying the acid haemolysis resistance of erythrocytes, we found significant changes in the stability of erythrocyte membranes (Table 2).

We observed a significant increase in the percentage of maximum haemolysis in all experimental groups. Therefore, it increased significantly to $33.8 \%$ in the $\mathrm{E} 1$ group, to $39 \%$ in the group E2, and to $33 \%$ in E3, compared to control. We found no significant differences between E1 and E3 groups in the percentage of maximum haemolysis.

ISSN 1996-4536 (print) • ISSN 2311-0783 (on-line) • Біологічні Студії / Studia Biologica • 2015 • Том 9/№3-4 • С. 57-68 


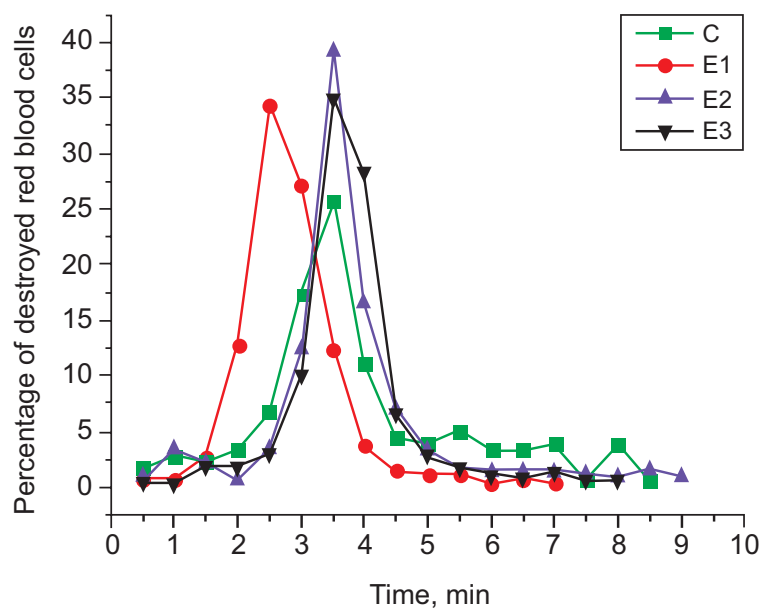

Fig. 2. Typical averaged erythrograms of acid haemolysis of rat's red blood cells

Рис. 2. Типові усереднені еритрограми кислотного гемолізу еритроцитів щурів

Table 2. Parameters of erythrograms of intact animals (C), and of rats exposed to CPF (E1), vitamin mixtures (E2), and vitamins with CPF (E3)

Таблиця 2. Параметри еритрограм інтактних тварин (C) і щурів, підданих дії хлорпірифосу (XПФ) (E1), суміші вітамінів (E2) та вітаміни з ХПФ (E3)

\begin{tabular}{|l|c|c|c|}
\multicolumn{1}{c|}{ Groups } & $\begin{array}{c}\text { Time of maximum } \\
\text { haemolysis, min }\end{array}$ & $\begin{array}{c}\text { Time of total } \\
\text { haemolysis, min }\end{array}$ & $\begin{array}{c}\text { Percentage of maximum } \\
\text { haemolysis, \% }\end{array}$ \\
\hline Control & $3.3 \pm 0.28$ & $8.5 \pm 0.28$ & $26.7 \pm 2.11$ \\
\hline E1(CPF) & $2.7 \pm 0.27$ & $7.0 \pm 0.70$ & $33.8 \pm 1.64^{*}$ \\
\hline E2 (vitamins) & $2.87 \pm 0.25$ & $9.2 \pm 0.22$ & $39.0 \pm 2.93^{*}$ \\
\hline E3(vit+CPF) & $3.25 \pm 0.26$ & $7.7 \pm 0.28$ & $33.0 \pm 1.51^{*}$
\end{tabular}

It is known that CPF is able to generate ROS [2, 22]. The newly formed ROS can increase, directly or indirectly, the passive permeability of membranes to potassium and sodium ions and cause violations in the erythrocyte osmotic balance, thus reducing the lifespan of these cells $[6,25]$.

The level of LPO, both primary LP (lipid hydroperoxides) and secondary (TBARS), is a feature of ROS generation. The results of our study show that in group E1 the amount of LP in erythrocyte haemolysate significantly increased by $40 \%$, compared to control (Fig. 3, I).

At the same time, the number of primary lipid peroxidation products significantly $(p<0.05)$ decreased $(32 \%)$ in the erythrocyte haemolysates of the E2 group, compared with the ones of intact animals. In the group E3, exposed to the combination of vitamin mixture and CPF, we observed more slight decrease in the number of LP than in E2: by $15 \%$, compared with control. At the E3 group amount of primary lipid peroxidation products significantly decreased by $39 \%$ compared with E1 group.

Changes in the content of TBARS were also found in the experimental groups (Fig. 3, II). So, the content of TBARS significantly increased in E1 (by $80 \%$ ) and E3 (by $49 \%$ ) groups, compared with control values. According to I. Amara and S. F. Ambali, the increase of lipid peroxidation products content shows the accumulation of hydrogen peroxide, nitrites, nitrates and other compounds, the amount of which exceeds the one that can be disposed in detoxification processes. These products can cause oxidative 
damage to membranes through interaction with polyunsaturated fatty acids (PUFAs) and haeme iron in the erythrocytes [1,2].

The catalase (CAT) and superoxide dismutase (SOD) activities are important indicators of the functional state of the erythrocyte antioxidant system. It is known that CAT is involved in utilization of hydrogen peroxide produced in the process of biological oxidation, decomposing it into water and molecular oxygen. In the presence of $\mathrm{H}_{2} \mathrm{O}_{2}$, it oxidizes low molecular alcohols and nitrites. SOD performs dismutation of superoxide radical into molecular oxygen or hydrogen peroxide [4].

We found a significant increase in CAT activity (by $34 \%$ ) in haemolysates of RBCs of E1 group, compared with the control (Fig. 4, I). Instead, SOD activity decreased significantly in erythrocytes haemolysate in groups E2 and E3, by 66 and $32 \%$, respectively (Fig. 4, II).
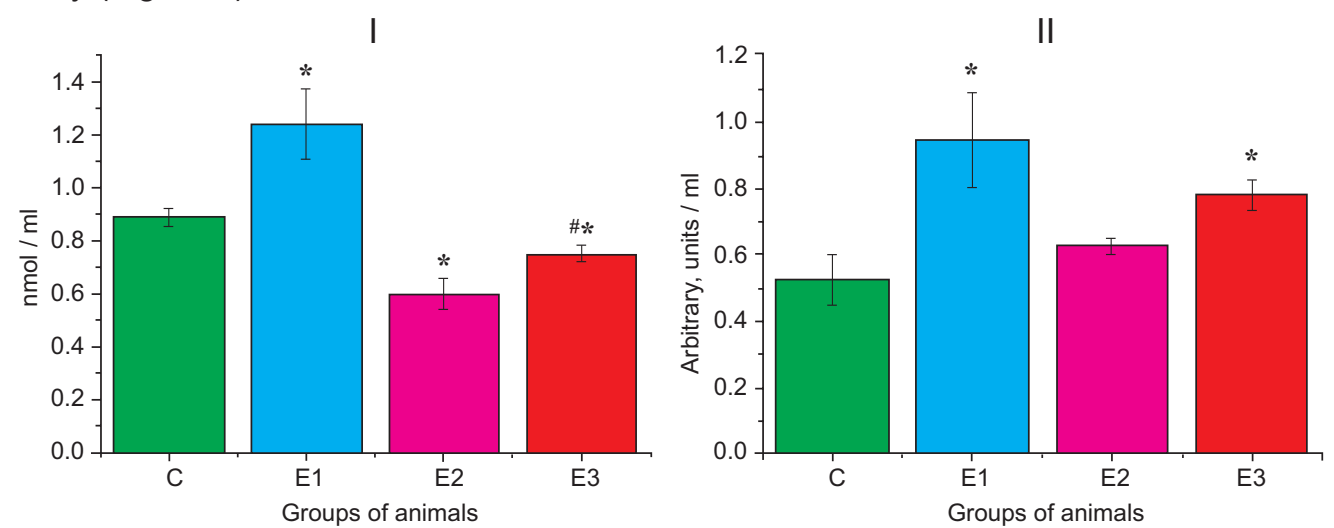

Fig. 3. $L P(I)$ and TBARS (II) content in the red blood cells of rats groups $C, E 1, E 2, E 3$

Рис. 3. Гідроперекиси ліпідів (I) і ТБК-активні продукти (II) в еритроцитах щурів груп С, Е1, Е2, Е3
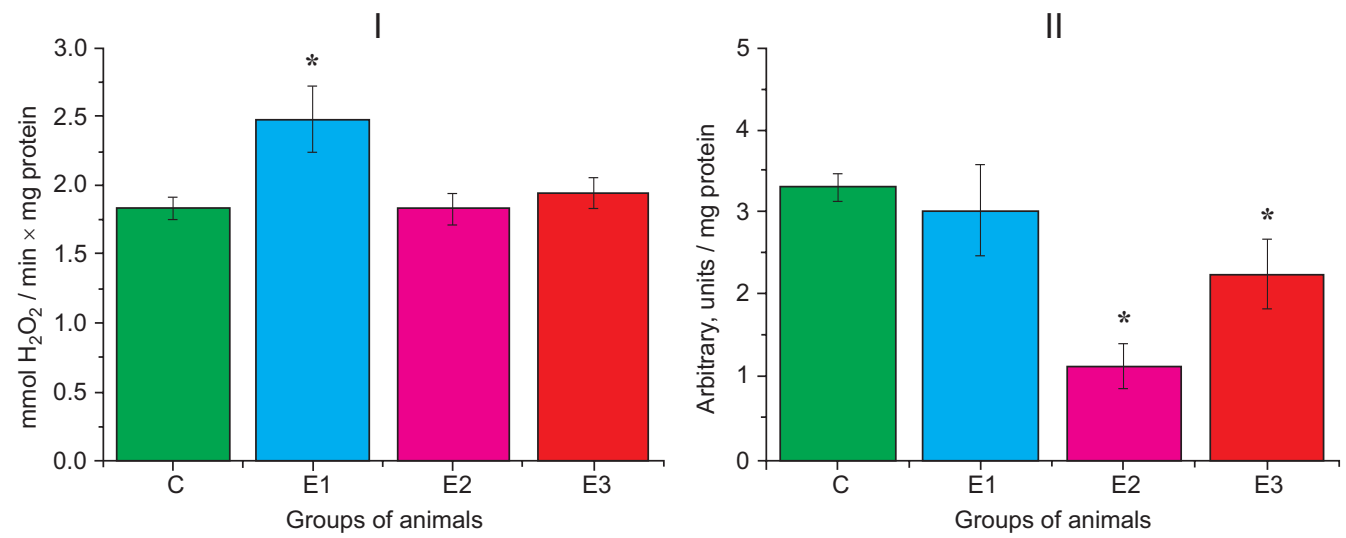

Fig. 4. CAT (I) and SOD (II) activity in the red blood cells of rats groups $C, E 1, E 2, E 3$

Рис. 4. Активність КАТ (I) і СОД (II) в еритроцитах щурів груп С, E1, E2, Е3

The glutathione system which includes glutathione and glutathione-dependent enzymes, has one of the leading roles in the utilization of ROS and the redox potential stability. This is due to synergism of glutathione-dependent enzymes, their participation

ISSN 1996-4536 (print) • ISSN 2311-0783 (on-line) • Біологічні Студії / Studia Biologica • 2015 • Том 9/№3-4 • С. 57-68 
in regeneration of some low-molecular antioxidants and the ability of glutathione to neutralize active oxygen intermediates through direct interaction [22]. We studied the content of GSH, GPO, and GR after 12 hours of CPF intoxication (Fig. 5).
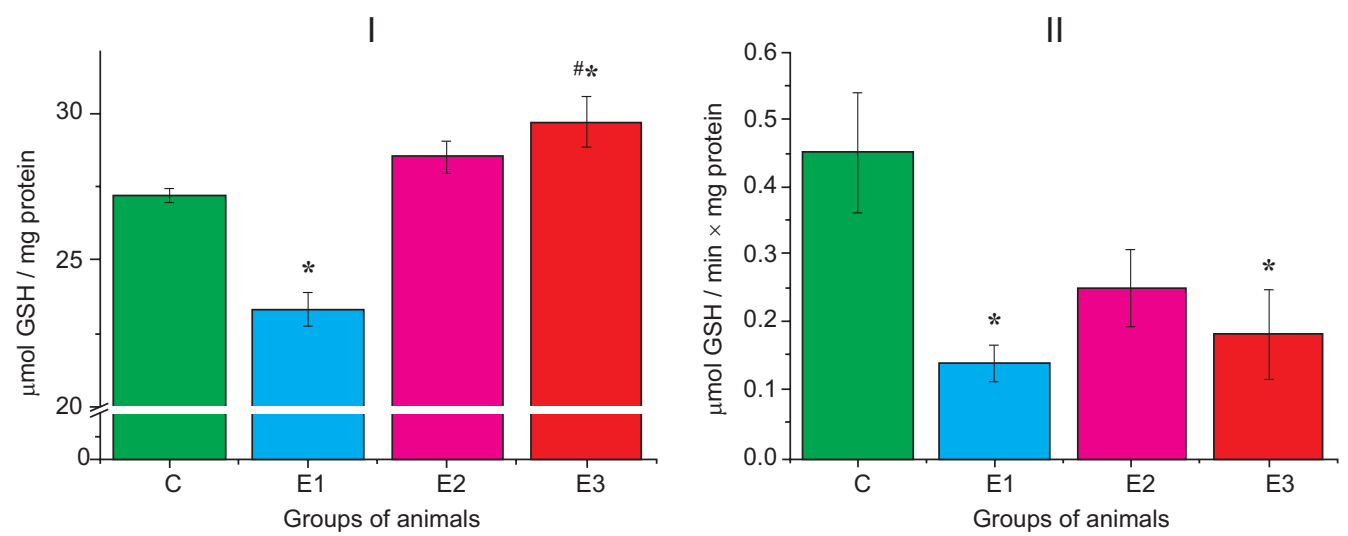

III

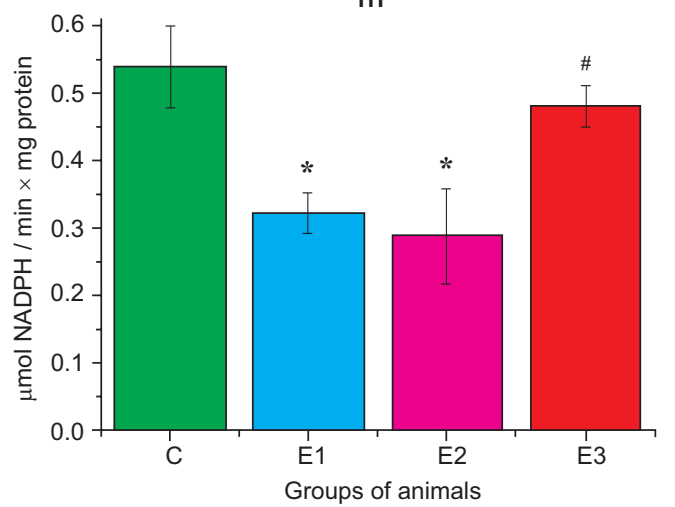

Fig. 5. GSH (I) content, GPO (II) and GR (III) activities in the red blood cells of rats groups C, E1, E2, E3

Рис. 5. Вміст глутатіону (I) й активність ГПО (II) та ГР (III) в еритроцитах щурів груп C, E1, E2, E3

The content of GSH decreased by $15 \%$ in the E1 group, while in the group E3 it increased by $9 \%$, compared to the control. Data in this study also show that GSH content in the group E3 increased by $27 \%$ if to compare with E1 group.

Activity of GPO in RBC haemolysates of E1 and E3 groups significantly decreased (by $70 \%$ and $60 \%$, respectively), compared to the control values. GR activity decreased by $40 \%$ in E1 and by $46 \%$ in E2, compared with the control. Treatment of CPF-intoxicated rats with vit A and $E$ significantly increased GR activity by $33 \%$ in group E3 if to compare with E1 group.

The reduction-oxidation cycle of glutathione is involved in regulation of oxidative stress, when the stress level is low [1]. The decrease of GSH content in erythrocyte haemolysates of E1 group is obviously connected with its consumption to maintain redox balance, particularly, when CPF affects mitochondrial metabolism [26]. Instead, higher glutathione levels under conditions of the correction of the toxic CPF effects by the vitamin mixture may indicates a decrease in the intensity of LPO, and perhaps even normalization of oxidative processes in the structures of rat erythrocytes. 


\section{CONCLUSIONS}

We found that acute exposure to $70 \mathrm{mg} / \mathrm{kg}$ CPF led to changes in haematological parameters: a decrease in the number of red blood cells, platelets, and total haemoglobin. After CPF exposure, a significant decrease in platelet count was observed in the peripheral blood of E1 group rats. In the E3 group we observed a significant increase in the total platelet number, compared to E1 group. We found slight corrective effect of vitamins $A$ and $E$ at the total number of platelets.

Besides, a decreased acidic haemolysis resistance in erythrocytes of CPF-intoxicated rats was found. The studied mixture of vitamins $A$ and $E$ showed a slight protective effect on these haematological parameters. The toxicant caused some biochemical changes, e.g. increase in the number of TBARS and lipid hydroperoxides content in the RBCs of rats after 12 hours of exposure. We found activation of LPO processes due to CPF intoxication and decrease in their intensity under the effect of vitamins $A$ and $E$. We also found an increase in CAT activity, and decreased SOD, GPO, GR activities and GSH content.

In conclusion, we consider that the correction of oxidative stress by vitamins had a positive effect on the biochemical parameters of rats.

1. Amara I. Dimethoate-induced oxidative damage in erythrocytes of female adult rats: possible protective effect of vitamin $E$ and selenium supplemented to diet. Toxicology and Industrial Health, 2011; 28(3): 222-237.

2. Ambali S.F., Ayo J.O., Ojo S.A. et. al. Vitamin E protects Wistar rats from chlorpyrifos-induced increase in erythrocyte osmotic fragility. Food Chem. Toxicol, 2010; 48(12): 3477-80.

3. Carlberg I. Purification and characterization of the flavoenzyme glutathione reductase from rat liver. J. Biol. Chem., 1975; 250: 5475-5480.

4. Chelikani P., Fita I., Loewen P. Diversity of structures and properties among catalases. Cell. Mol. Life Sci, 2004; 61(2): 192-208.

5. Dubinina E.E. The biological role of superoxide anion radical, and superoxide dismutase in body tissues. The Success. of Mod. Biol, 1989; 108(1): 3-18. (In Russian).

6. Dudok K., Starykovych L., Rechytskyi A. et. al. Role of pyrrolopyrimidinedions derivatives in the regulation of haemoglobin physical and chemical characteristics and human blood antioxidant enzymes activity in vitro. Visnyk of Lviv University. Series Biology. 2012; 60: 126136. (In Ukrainian).

7. Gitel'zon I. I., Terskov I. A. The erythrogram as a method of clinical investigation of the blood. Krasnoyarsk: Scientific academy of USSR, Siberia department; 1959: 246. (In Russian).

8. Grabovska S., Rosalovsky V., Salyha Y. Neurotoxic effects and other actual risks of chlorpyrifos. In: A. Sibirny, et al. (Ed.) Living organisms and bioanalytical aproaches for detoxification and monitoring of toxic compounds. Univ. of Rzeszow, 2015; 195-204.

9. Grabovska S.V., Salyha Y.T. The effect of chronic intoxication with low doses of chlorpyrifos on the behavioral parameters of female rats. Fiziolohichnyi Zhurnal, 2014; 61(2): 94-101. (In Ukrainian).

10. Hassani S., Sepand M.R., Jafari A. et al. Protective effects of curcumin and vitamin E against chlorpyrifos-induced lung oxidative damage. Hum Exp Toxicol, 2015; 34(6): 668-76.

11. Hissin P.J., Hilf R.A. A fluorometric method for determination of oxidized and reduced glutathione in tissues. Analyt. Biochem, 1976; 74: 214-226.

12. Karpyshtshenko A. Medical laboratory technologies and diagnostics: Handbook. St. Petersburg: Intermedica, 1999. 656 p. (In Russian).

ISSN 1996-4536 (print) • ISSN 2311-0783 (on-line) • Біологічні Студії / Studia Biologica • 2015 • Том 9/№3-4 • С. 57-68 
13. Kharchenko O.A. Balan G.M., Bubalo N.N. Acute organophosphate poisoning: the main clinical syndromes and mechanisms of their formation (literature review and own research data). Modern Problems of Toxicology, 2013; 1(2): 17-31. (In Russian).

14. Korobeynikova E.A. modification of lipid peroxidation products assessment in the reaction with thiobarbituric acid. Lab. Delo, 1989; 7: 8-9. (In Russian).

15. Koroliuk M.A., Ivanova L.I., Mayorov I.G. et al. The method of determining the activity of catalase. Lab. Delo, 1988; 1: 16-18. (In Russian).

16. Lowry O.H. Rosebrough N.J., Farr A.L. et al. Protein measurement with the Folin phenol reagent. J. Biol. Chem, 1951; 193(1): 265-75.

17. Mashali $A$. Role of oxidative stress and apoptosis in acute organophosphorus intoxicated patients. JMRI, 2005; 26(3): 255-263.

18. Moin V.A. simple and specific method for glutathione peroxidase activity assessment in erythrocytes. Lab. Delo, 1986; 12: 724-727. (In Russian).

19. Rosalovsky V.P. Haematological indices of rats during the first hour after chlorpyrifos exposure. Biological Bulletin of Bohdan Chmelnitsky Melitopol State Pedagogical University, 2015; 1: 123-132.

20. Salyha Y. Biological effects assessment of chlorpyrifos and some aspects of its neurotoxicity. Visnyk of Lviv University. Biology Series, 2010; 54: 3-14.

21. Salyha Y.T. Antioxidant system indices in brain of rats intoxicated by chlorpyrifos. Studia Biologica, 2013; 7(3): 85-96. (In Ukrainian).

22. Salyha, Yu.T. Chlorpyrifos leads to oxidative stress-induced death of hippocampal cells in vitro. Neurophysiology, 2013; 45 (3): 193-199.

23. Sidhu I.P., Bhatti J.S., Bhatti G.K. Modulatory action of melatonin against chlorpyrifos induced hepatotoxicity in Wistar rats. Asian Journal of Multidisciplinary Studies, 2014; 2(9): 123-131.

24. Spodniewska A. Barski D. Gizejewska A. Effect of enrofloxacin and chlorpyrifos on the levels of vitamins A and E in Wistar rats. Environ. Toxicol. Pharmacol, 2015; 40(2): 587-91.

25. Vasilyeva E. M. Biochemical features of red blood cell. Effect of pathology. Biomedical Chemistry, 2005; 51(2) 118-126. (In Russian).

26. Venkatesh S., Ramachandran A., Zachariah A. et al. Mitochondrial ATP synthase inhibition and nitric oxide are involved in muscle weakness that occurs in acute exposure of rats to monocrotophos. Toxicol. Mech. Methods, 2009; (3): 239-45.

27. Vlizlo V.V., Fedoruk R.S., Ratych I.B. Laboratory methods of research in biology, animal husbandry and veterinary medicine. Lviv: Spolom, 2012. 764 c. (In Ukrainian).

28. Vlizlo V.V., Salyha.Y.T. Problems of biological safety of pesticides in Ukraine. Bulletin of Agrarian Science, 2011; 1: 24-27. (In Ukrainian).

ISSN 1996-4536 (print) • ISSN 2311-0783 (on-line) • Біологічні Студії / Studia Biologica • 2015 • Том 9/№3-4 • С. 57-68 


\title{
ЗМІНИ БІОХІМІЧНИХ І ГЕМАТОЛОГІЧНИХ ПОКАЗНИКІВ ПЕРИФЕРИЧНОЇ КРОВІ ЩУРІВ ЗА ДІЇ ХЛОРПІРИФОСУ: ЗАХИСНИЙ ВПЛИВ ВІТАМІНІВ А ТАЕ
}

\author{
В. П. Росаловський, С. В. Грабовська, Ю. Т. Салига \\ Інститут біології тварин НААН України, вул. В. Стуса, 38, Львів 79034, Україна \\ e-mail:ros.volodymyr@gmail.com
}

Хлорпірифос $є$ високотоксичною фросфорорганічною сполукою. Він залишається одним з найбільш поширених інсектицидів. Основний механізм його токсичності пов'язаний з інгібуванням холінестерази. Поряд із антихолінестеразними механізмами хлорпірифос може чинити вплив через інші біохімічні механізми, зокрема, через порушення про- і антиоксидантний баланс викликати генерацію вільних радикалів та спричиняти оксидаційний стрес.

Ми вивчили дію вітамінів A і Е на основні гематологічні та біохімічні параметри перифреричної крові щурів через годин 12 після одноразової інтоксикації хлорпірифосом. Введення хлорпірифосу у дозі 70 мг/кг спричиняло зниження загальної кількості еритроцитів, тромбоцитів і загального вмісту гемоглобіну. Ми виявили зниження стійкості еритроцитів периферичної крові до кислотного гемолізу у щурів інтоксикованих хлорпірифосом. Отруєння хлорпірифосом спричиняє зростання кількості продуктів перекисного окислення ліпідів: гідроперекисів ліпідів і ТБКактивних продуктів.

Введення вітамінів А і Е при інтоксикації спричиняє нівелюючий ефект на фрормування продуктів перекисного окислення ліпідів. У разі інтоксикації хлорпірифосом активність каталази зростала, тоді як активність супероксиддисмутази, глутатіонпероксидази, глутатіонредуктази і вміст відновленого глутатіону знижувались. Виявлено, що поєднання вітамінів А і E викликає коригувальний вплив на кількість тромбоцитів, вміст гідроперекисів ліпідів і ТБК-активних продуктів у периферичній крові щурів.

Ключові слова: хлорпірифос, вітамін Е, вітамін А, інтоксикація, щурі.

\section{ИЗМЕНЕНИЯ БИОХИМИЧЕСКИХ И ГЕМАТОЛОГИЧЕСКИХ ПОКАЗАТЕЛЕЙ ПЕРИФЕРИЧЕСКОЙ КРОВИ КРЫС ПОД ВОЗДЕЙСТВИЕМ ХЛОРПИРИФОСА: ЗАЩИТНОЕ ВЛИЯНИЕ ВИТАМИНОВ А И Е}

\author{
В. П. Росаловский, С. В. Грабовская, Ю. Т. Салыга \\ Институт биологии животных НААН Украины, ул. В. Стуса, 38, Львов 79034, Украина \\ e-mail:ros.volodymyr@gmail.com
}

Хлорпирифос является высокотоксичным фоссророрганическим соединением. До сих пор он остается одним из самых распространенных инсектицидов. Основной механизм его токсичности связан с ингибированием холинэстеразы. Наряду с антихолинестеразными механизмами хлорпирифос может оказать влияние через биохимические механизмы, в частности, посредством нарушения про- и антиоксидантного баланса вызвать генерацию свободных радикалов и обусловить возникновение окислительного стресса.

Мы изучили воздействие витаминов А и $\mathrm{E}$ на основные гематологические и биохимические параметры периферической крови крыс через часов 12 после однократ-

ISSN 1996-4536 (print) • ISSN 2311-0783 (on-line) • Біологічні Студії / Studia Biologica • 2015 • Том 9/№3-4 • С. 57-68 
ной интоксикации хлорпирифосом. Введение хлорпирифоса в дозе 70 мг/кг вызывало снижение общего количества эритроцитов, тромбоцитов и общего содержания гемоглобина. Мы обнаружили снижение устойчивости эритроцитов периферической крови к кислотному гемолизу у крыс, интоксицированных хлорпирифосом. Отравление хлорпирифосом приводит к повышению количества продуктов перекисного окисления липидов: гидроперекисей липидов и ТБК-активных продуктов.

Вместе с тем, введение витаминов А и Е при интоксикации вызывает нивелирующий эффект на формирование продуктов перекисного окисления липидов. При интоксикации хлорпирифосом активность каталазы повышалась, тогда как активность супероксиддисмутазы, глутатионпероксидазы, глутатионредуктазы и содержание восстановленного глутатиона снижались. Обнаружено, что сочетание витаминов А и Е вызывает корректирующее воздействие на количество тромбоцитов, содержание гидроперекисей липидов и ТБК-активных продуктов в периферической крови крыс.

Ключевые слова: хлорпирифос, витамин Е, витамин А, интоксикация, крысы. 